\title{
Developing Islamic Science Based Integrated Teaching Materials for Islamic Education in Islamic High School
}

\author{
Suparjo ${ }^{1 *}$, Muh. Hanif ${ }^{1}$, Dimas Indianto $\mathbf{S}^{1}$ \\ ${ }^{1}$ State Institute for Islamic Studies Purwokerto, Purwokerto, Indonesia
}

\begin{abstract}
This study aims to develop valid and reliable Islamic Education (PAI) teaching materials based on integrative Islamic science in Class X of Islamic High School in Indonesia. This research uses Borg \& Gall's research and development model. The results showed that the content and construct validity of the teaching materials for Islamic Education based on integrative Islamic science in Class X of Islamic Senior High School are valid and qualified for factor analysis. The teaching materials for Islamic Education meet reliability criteria. The feasibility level of Islamic Religious Education Integrative Islamic Science Class X of Islamic Senior High School is determined by four product assessment activities; material expert validation, media expert validation, limited trials, and readability trials. The results of the validation of material experts from 8 aspects of the assessment obtained on average 3.33 and classified as "Excellent", the validation results of media experts from 7 aspects of the assessment obtained on average 3.23 with "Good" classification, limited trials of 2 aspects of the assessment obtained an average of 3.54 classified as "Excellent" and the legibility trials of the 2 aspects of the assessment obtained an average of 3.60 with "Excellent" classification. The total average is 3.43 in the "Excellent" classification.
\end{abstract}

Keywords: Islamic education; Integrative science; Teaching materials;

\section{INTRODUCTION}

The books of Islamic Education and Character from curriculum 2013 emphasize the dimensions of character formation or akhlakul karimah in addition to building knowledge about Islam. The scientific dimension becomes the basis for strengthening moral attitudes and behaviors or moral actions (Lickona, 2009), hence, a righteous human being or noble personality is formed individually and socially (Lickona, 2012). The content of the book in general has used a scientific approach following the characteristics of Islamic Education and concentrates on strengthening the students' morality. However, the integrative Islamic science approach has not been maximally used in developing the teaching materials for Islamic Education, because the paradigm developed in the curriculum is still dominated by Islamic knowledge for science and moral formation rather than as an integrative Islamic scientific construction.

Through textbook analysis of the teaching materials for Islamic Education and Character, it was found 5 (five) main indicators. First, the textbook has not integrated the result of research on Islamic sciences such as Qur'an and Hadith, Aqidah and Akhlak, Fiqh, and Islamic Cultural History, with natural sciences, humanities, or social sciences. For example, the theme of Asmaul Husna, Allah Al-Khaliq (the Creator) can be related to the theory of creation or Allah Al-Muhaimin with the theory of rain or solar system.

Second, the materials in Islamic Education book is always presented from the normative dimension by quoting the Quranic verses or Hadith followed by the evidence, explanation, and elaboration with persuasive da'wah approach to emphasize teaching positive behavior and avoid negative behavior. This kind of presentation pattern does not urge the development of students' critical and creative reasoning. Students can be given illustrations of related stories to the theme, directions for reasoning, researching, or connecting the scientific theories with the dalil or Islamic knowledge such as verses or Hadith along with the elaboration to give understanding for the students that science and religion can be integrated.

Third, the development of a critical and productive scientific mindset has been developed through an independent task rubric but has not been brought towards the science and morality context as a whole. For example, the theme of Adultery is only discussed in Ushul Figh perspective by establishing Islamic law, rather than as a social study which can be seen from sociological, cultural, psychological, economic, cultural, and humanitarian perspectives.

Fourth, the books have provided competency test which encourages students to develop Middle Order Thinking Skills

Corresponding Author e-mail: suparjo@iainpurwokerto.ac.id https://orcid.org/0000-0001-7975-3774

How to cite this article: Suparjo, Hanif M, Indianto DS (2021). Developing Islamic Science Based Integrated Teaching Materials for Islamic Education in Islamic High School. Pegem Journal of Education and Instruction, Vol. 11, No. 4, 2021, 282-289

Source of support: Nil

Conflict of interest: None.

DOI: 10.47750/pegegog.11.04.27

Received: 10.09.2021

Accepted: 10.09.2021 Publication: 01.10.2021 
(MOTS) and Higher Order Thinking Skills (HOTS). However, the competency test has not been specifically established to direct students to be able to integrate the Islamic perspective with science as a unified point of view at the high school level. The development of competency tests also has not integrated religion and science or science with morals. The scarcity of this construction causes the nomenclature of Islamic religious education and character building.

Fifth, the book has included Quranic verses and Hadith as the references, but students have not been directed to explore and develop basic competencies through media sources that allow students to develop their knowledge while building their character (Mustahdi \& Mustakim, 2014).

Therefore, presenting Islamic religious education with an integrative approach (integrated between science and religion) is very important both scientifically and for the student's character development. Dichotomous scientific development potentially causing split personality can be avoided. It means that students can become scientific and religious individuals at the same time. Therefore, this study aims to provide an alternative textbook that uses an integrative approach between religion and science.

In the scientific dimension, the development of textbooks with integrative Islamic science paradigm within the ideal range becomes urgent to realize the project of Islamization formulated by Muslim scientists, such as Ismail Raji al-Faruqi (Islamization of science), Sayyid Naquib al-Attas (Islamic Science), Oesman Bakr (Islamic Science), Mehdi Ghosani (Islamic science), Kuntowijoyo (Islamic Science), Armahedi Mahzar (Integral Islamic Science), Amin Abdullah (integration of spider model science) and Imam Suprayogo (Tree of Science). Epistemologically, this study is also very urgent to realize the idealism of the 2013 curriculum that focuses on a scientific and character-based approach in which religious character becomes the basis of character values. Therefore, an integrated textbook that combines science and religious knowledge is important to modernize students with scientific indications and at the same time ethics represented by religious characters.

In character construction, the development of a textbook model that integrates religion and science is an important element in shaping a Muslim personality with a scientific attitude integrate with religious attitudes. This attitude will keep students from splitting their personalities not to be extreme rightists who supporting radicalism or extreme left supporting secularism. The split personality is caused by an understanding of science and religion in the dichotomous of the curriculum, and partly because the books tend to favor secularization and dichotomy. Therefore, the development of integrative Islamic science textbooks is important to develop students' personality as a whole, scientific and at the same time religious.
Practically, there is a dynamic correlation between Muslim intellectual views and attitudes towards the integration of religion and science as constructed in the Islamic epistemology system. It implies the development of education and teaching materials. It resulted in the development of Islamic institutions, for example in Central Java and Yogyakarta Special Region such as Al-Irsyad Al Islamiyah, An-Nida Purwokerto, Putra Harapan, Harapan Bunda, Sekolah Alam, and Kuttab Al-Fatih (Purwokerto), Yayasan Sambas (Purbalingga), Pesantren Ali Maksum and Pesantren Wahid Hasyim (Yogyakarta), and Pesantren Futuhiyyah (Demak). These institutions have accelerated institutional development, academic, and public acceptance. This represents an acceleration of the dynamics acceptance and development of integrative Islamic science among Islamic education developers and managers. Every developer and manager of Islamic educations has their vision and idealism with the integration of faith, science, and morality in education. However, their efforts have not been realized until they publish teaching materials with an integrative Islamic science paradigm.

Based on the background of this problem, this research is oriented to produce integrative paradigms textbooks to shape and strengthen students' religious-scientific character. This research is to reconstruct the model of Islamic Religious Education (PAI) teaching materials based on integral Islamic science as an effort to develop students' scientific-religious character in Islamic educational institutions.

\section{Methods}

The method used in this study is development (Research \& Development). The research and development procedure consists of two main objectives: developing the product and testing the effectiveness of the product in achieving the goal. The main purpose is referred to as the development function, while the second goal is referred to as the validation function. The research and development model used in this research refers to the research model developed by Borg \& Gall (Sugiyono, 2010). The data is used to assess the quality of Islamic Religious Education teaching materials based on integrative Islamic science to be feasible to use. The data consists of quantitative and qualitative data. Quantitative data is the main data from experts and students on the assessment of teaching materials. The qualitative data is acquired from the material and media experts as well as from the students taken during the limited and legibility trials to test the validity. This data is in the form of opinion, input, and suggestions.

\section{Result and Discussion The Design of Textbook Development}

The success of the learning process is determined by many factors intertwined with each other including 
educators, students, infrastructure, and other components (M.M. Abdullah, 2019). Thus, an effective learning process can be seen from the interaction between these components in achieving the learning objectives (Hossain, 2015).

Teaching materials are one of the important factors besides educators, students, facilities, and other components. Good teaching materials are those that can motivate students to learn more vigorously and develop the students' potential (Hossain, 2015).

According to the National Centre for Competency-Based Training (2007), Teaching materials are all the materials used to assist teachers/instructors in teaching and learning activities in the classroom. The teaching material can be written or unwritten material (Mudlofir, 2011; Teaching materials can also be interpreted as information, tools, or text used by the teachers in the teaching and learning process. Teaching materials are a set of materials that are systematically arranged both written and unwritten to create an environment or atmosphere that allows students to learn, such as textbooks, handouts, student worksheets, modules, etc.

Teaching materials are designed in such a way concerning the type, scope, order, and treatment. The type of learning materials also needs to be identified appropriately, because each teaching material requires media, evaluation techniques, and different methods (M.M. Abdullah, 2019). The material profoundness or scope also needs to be considered appropriately based on the students' level. Other things that need to be considered are the order of the teaching materials to create coherent teaching and learning process. In addition, the treatment of teaching materials needs to be selected appropriately so that the teaching material can be identified (what material needs to be memorized, understood, and applied). Hence, the teacher will not be mistaken in delivering the teaching materials to students.

The development of teaching materials have several important roles including: (1) Guidelines for teachers to direct the activities in the learning process, as well as the substance of competence that should be taught to students, (2) Guidelines for students for the learning process, as well as the substance of competence that should be studied, and (3) Tools for achievement evaluation of achievement (Johar \&Hanum, 2016). Therefore, the development of teaching materials aims and is useful to (1) assist students in learning something, (2) provide a variety of choices of teaching materials, (3) facilitate teachers in the implementation of learning, and (4) to make learning activities more interesting.

The theory of the development of teaching materials includes preparation, adaption, adoption, translation, and revision. In this context, this research adopts and revises existing textbooks based on the curriculum by integrating religion and science.
There are at least five teaching material development models such as Kemp development model, Dick \& Carey development model, Borg \&Gall development model, PPSI development model, and 4-D development model (Four D). First, the development of Jerrold E. Kemp's model allows the developers to start from any component. Since, the curriculum is nationally applicable in Indonesia and oriented to the goal, thus, the development process starts from the goal. Kemp's model has the advantage of giving a holistic view in one stage of learning. Second, the Dick and Cerey development model is similar to the model Kemp developed added with learning analysis and several components for the development and planning process. Third, the Borg \&Gall development theory is a development model consisting of ten steps that can be modified according to the researcher's needs. The pattern or cycle of development includes the collection of information, planning, product design, product design validation, product revision, product trials, product revisions, and textbook production. Fourth, the theory of learning development model PPSI (Instructional System Development Procedure) is a unit of learning system development in which teaching materials or textbooks become part of it. Development patterns and cycles include the formulation of objectives, development of evaluation tools, learning activities, development of activity programs, to the implementation of development. Fourth, the 4 -D development model or also called 4-P that specifically develops a model of teaching materials consisting of 4 main stages; Defining, Designing, Developing, and Disseminating. The first four theories of development provide holistic learning models, while the latter, the 4-D model is a specific theory of the development of teaching materials and textbooks. Therefore, the 4-D theory was chosen as the development model. Developed by S. Thagarajan, Dorothy S. Semmel, and Melvyn I. Semmel, the 4-D development model consists of 4 main stages; Define, Design, Develop, and Disseminate (Trianto, 2012).

\section{Integrative Islamic Science}

The term science subjects in the development of national education began since the enactment of the curriculum in 1984. Nowadays the term science has become more popular than knowledge, due to the influence of the 21st-century globalization era. Long before that science subjects were known as life sciences for biology, earth sciences, natural sciences for physics and chemistry, and so on.

Science itself is derived from the Latin Scientia which means science in general. At least, there is one fundamental that distinguishes between science and non-science that is a methodology experiments. In astronomy, however, an astronomer can't do experiments in the sky. Astronomers replaced experimental activities with astronomical observations of information couriers such as electromagnetic waves, 
meteorites, neutrinos, or gravitational waves very carefully (Sunhaji, 2013).

Sunhaji cites Ardley's opinion defines science as a series of conceptual concepts and schemes that relate to each other and grow as a result of experimentation and observation and useful for observation and experimentation. Further, Sunhaji quotes Elland suggests that science is a system for understanding the universe through controlled observations and experiments (Sunhaji, 2013). Thus, it can be understood that the main feature of science is the existence of methodology in it. Science is not only limited to the natural sciences but can also be found in social sciences. This is because in reality, social symptoms in society are an object that can not only be observed, but also can be experimented. In addition to methodology, there is another peculiarity of science, that is how to develop a theory. In this case, experiments or observations are part of the process of building a theory, explaining the results of experiments in more general theories. By understanding experimental and observation techniques (empirical) and constructing a theory, secrets or mysteries in the universe can be revealed one by one. Humans can benefit from the understanding of the universe. Therefore, fundamentally the difference between science and non-science lies in the methodology and how to build the theory.

\section{Bridge of Religious Integration and Science}

The term integration is not actually a foreign term for some people who struggle in social sciences. Although the term integration can be used in all scientific fields, it is mostly used in social sciences, especially those that discuss the life of a society. However, this does not mean that the term CA not be used in other fields. In general, there are no restrictions on the use of integration terms only on certain fields. The term integration is very likely to be used in other fields including education.

Linguistically, integration is the unification to become a whole or unanimous unity. In social sciences, the concept of integration is mainly related to the process of acculturation, namely the process of "transmission" of cultural values of a social system with different cultural patterns. This transmission occurs through the diffusion process, which is the meeting of social actors from two different social systems of cultural patterns, who have social contacts and communicates each other exchanging their ideas. The cultural process then formed a new pattern of relationships or social structures to accommodate the realization of values and norms as a result of the diffusion process, then it is called as an integration. In addition to the above definitions there are several other definitions of integration. Integration is juxtaposing two different perspectives on one/more of the same phenomena to find a meeting point in one truth. It means that integration happens when there are some things that can't be reconciled.
Therefore, with integration, it is expected to merge those things to achieve a common goal. It can simply be understood that the integration of science and Islam is an attempt to unify science and Islam in order to achieve the same goal.

One of the most popular terms used in the context of the integration of religious sciences and general sciences is the word "Islamization". According to Echols and Hasan Sadily, the word islamization comes from the English Islamization which means islamization. In Webster's dictionary, Islamization means to bring within Islam. The broader meaning is to refer to the process of islam, where the object is a person or a human being, not science or other objects.

Based on that term, a model of religious integration with science was built. Science refers to natural or social sciences, while Islam is legally formally the name of a religion on earth. Therefore, integration of science and Islam means integration of science and religion - although the word "religion" is not limited to Islam. The discussion of the integration of Islam with science can not be separated from the theory of Ian G. Barbour. He argues that science and religion can be integrated intensively and systematically as a natural theology construction, in which the science becomes a scientific explanation of theology and vice versa, theology provides a strong teleological and philosophical meaning and answer to the science. As a result, both science and Islam must be able to support and strengthen each other.

The second theory of science integration was adopted from Armahedi Mahzar who suggests that the Islamization of science as a continued reorientation of the science paradigm by responding critically and creatively to the negative impact of science and combined with the Islamic paradigm (Makbuloh \&Ruswanto, 2020). Therefore, Islamic science is not just a static product of science, but it needs systematic, dynamic and sustainable engineering. This indicates that muslim scientists should not only be busy looking for verses from an existing invention, but should be able to find new theories after reading verse in the Qur'an (Nugroho, 2017).

Mahzar offers two stages related to the integration of science with Islam; (1) the integration of the paradigm of atomism with the paradigm of cybernetic holism so that it becomes a view of scientific objectivism theology, (2) integrate the view of scientific objectivism with the religious views and cultural subjectivism so that it becomes an integral and universal science paradigm. Thus religion, culture, science and technology become subjective, intersubjective, objective and interobjective aspects of the integral unity of human knowledge (Bhat, 2016).

According to Armahedi Mahzar - as quoted by Luthfi Hadi Aminuddin - there are at least 3 (three) models of integration of science and religion; monadik, diadik and triadik models (Efrinaldi et al., 2020). First, the monadic model is a popular model among religious and secular fundamentalists. 
Religious fundamentalists assume that religion is a universal concept containing all branches of culture. Religion is considered the only truth and science is only one branch of culture. Whereas according to secular circles, religion is just one branch of culture. Therefore, it is culture that is the expression of man in realizing their life based on science as the only truth. With this monadic model, there is no coexistence between religion and science, because both confirm the existence or truth of the other (Ephrinaldi et al., 2020).

Second, the diadik model. This model has several variants. First, the variant states that science and religion are two equal truths. Science talks about natural phenomenon, while religion talks about divine values. The second variant believe that religion and science are inseparable. While the third variant argues that between religion and science have something in common. This similarity can be used as a material for the integration of the two.

Third, the triadic model. In this triadic model there is a third element that bridges science and religion. That bridge is philosophy. This model was put forward by the theosophyses who say "there is no religion higher than truth," Truth is the togetherness between science, philosophy and religion (Aminuddin, 2010). This model is an extension of the diadic model, incorporating philosophy as the third component as a liaison to science and religion. This model may still be biased so that it is redeveloped by replacing the third component with humanities or cultural sciences.

\section{Model of the Relationship between Religion and Science in Schools}

In general, the schools that becomes the objects of this research uses the dialogue model for their integration between religion and sciences. In this model, religion and science are compromised for interrelationship. Similar to Ian Barbour's argument states that this type of dialogue arises by considering preconceptions in scientific efforts, or exploring the parallels methods between science and religion, or analyzing concepts in one field with another concepts. In comparing science and religion, dialogue emphasizes preconceional similarities, methods, and concepts.

The conflict between the Islamization of Science and the Science of Islam constructing the integration between science and islam. Integration-interconnection among three worlds; Islamic studies, philosophy, and Science and Technology (Science and Technology). The interwoven of these "three worlds" marks the beginning of the third wave in the relationship between religion and science. This third wave is referred to by Alvin Toffler as holistic. Some terms have been used by Western and Islamic philosophers, as a bridge of integration between religion and science, for example Amin Abdullah's "interconnected”, Auda's "interrelatednees", Knott's "Rapprochment", An-Naim's "Reciprocity" and
al-Jabiri using the term irfani, to bridge between bayani and burhani (Riyanto, 2013).

The paradigm of interconnection initiated by $\mathrm{M}$ Amin Abdullah tries to connect the trilogy between subjective, objective, and intersubjective values (Nasrullah, 2016). The research agenda to build a framework of fundamental philosophy methodology that directly related to religious and Islamic studies which aim to solve the problem of religious plurality is like looking for a needle in the darkness. It needs flashlight to illuminate to find it. The flashlight is the meeting of three clusters between sciences based on religious texts (naql, bayani; subjective), and sciences based on reasoning and understanding the sociological-anthropological reality of cultural and religious plurality ('aql, burhani; objective) and sciences of human conscience (qalb, 'irfani, intuitive; intersubjective passion).

According to Amin Abdullah integration-interconnection is a trialectic between the tradition of text (hadarat an-nas), academic-scientific tradition (hadarat al-ilmu), and tradition of ethics-critical (hadarat al-philosophy) (Anshori \&Abidin, 2014). The epistemology of M.Amin Abdullah's integrationinterconnection is systematically formulated in the following figure 1.

The first layer of the above cobweb images are the Qur'an and Hadith as normative sources of Islam. The second layer is various approaches, methods, and focus of the object. The first layer with various approaches and methods of study in the second layer create the third layer, the traditional Islamic sciences such as tafsir, Hadith, kalam, figh, Sufism, lughah (language), date, and philosophy. The development of modern science and methodology as illustrated in the natural and social-humanities sciences created from the integration of the third layer with the fourth layer such as history, philosophy, psychology, sociology, anthropology, archaeology, philology, and etc. Islamic sciences in the third layer can also inspire and enrich thie development of sciences in the fourth layer.

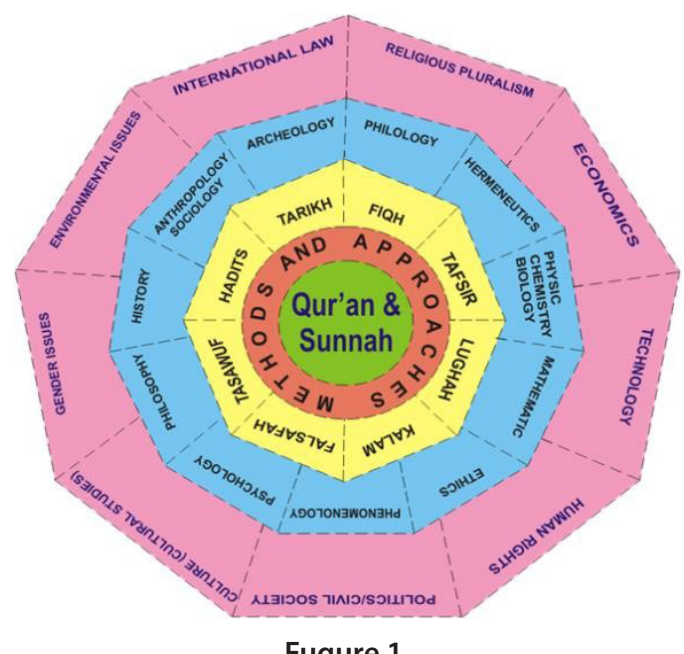

Fugure 1. 
Intercommunication between layers and between disciplines in one layer will disprove new sciences, and the development of integrative-interconnective Islamic science in the last layer which current issues such as religious pluralism, international law, democracy, environmental ethics, gender, human rights and others (A. Abdullah, 2003).

Amin Abdullah on another occasion connected the cobweb scheme with Keith Ward's conception of the history of the religious studies development through 4 (four) phases; local, canonical, critical, and global. In the first stage, the local phase, all religions in the prehistorical period era can be categorized as local. In the second phase, canonical or propositional phase, is the era of religions. The third stage is the critical phase. In the 16th and 17th centuries, religious consciousness in Europe underwent a radical change in the Enlightenment movement. The fourth stage is the global phase as it is happening today and rise new science as well as more critical methods which is not only fixated on the ratio. This is seen in the fourth circle of cobwebs depicting Islamic science with integrativeinterconnective paradigms expecting the development of Islamic sciences that are not only focused on one layer or two, but also to the third and fourth layers. The first and second layer are referred to as "Ulumuddin" which is a representation of islamic "local traditions" based on "language" and "texts" or religious texts. The third circle is referred to as al-fikr al-Islamiy as the representation of the struggle of islamic thought based on "intellect-ratio". While the fourth circle is called as dirasat islamiyyah or Islamic Studies as a new scientific cluster based on the paradigm of critical-comparative of social sciences because it involves the whole of mankind's "experiences" in the diverse historical-empirical realm (Anshori \&Abidin, 2014).

Interpretation of nash, Qur'an and Hadith, does not leave the wholeness of reality as developed in philosophy, and also does not ignore the scientific perspectives of various disciplines (Anshori \&Abidin, 2014). Islamic sciences are developed not

Table 1: Three Scientific Paradigms

\begin{tabular}{|c|c|c|}
\hline Paradigm & Characteristic & Character \\
\hline $\begin{array}{l}\text { Islamization of } \\
\text { Knowledge }\end{array}$ & $\begin{array}{l}\text { Subjectivity (ISTAC } \\
\text { and IIUM } \\
\text { Malaysia as well } \\
\text { as several UIN in } \\
\text { Indonesia) }\end{array}$ & $\begin{array}{l}\text { Al-Attas and Ismail } \\
\text { al-Faruqi }\end{array}$ \\
\hline $\begin{array}{l}\text { Scientification of } \\
\text { Islam }\end{array}$ & $\begin{array}{l}\text { Objectivity (Multiple } \\
\text { UIN in Indonesia) }\end{array}$ & $\begin{array}{l}\text { Arkoen, Fazlur } \\
\text { Rahman, } \\
\text { Kuntowijoyo }\end{array}$ \\
\hline $\begin{array}{l}\text { Integration- Scientific } \\
\text { Interconnection }\end{array}$ & $\begin{array}{l}\text { Circkulatif- } \\
\text { Hermeneutis } \\
\text { between Subjectivity, } \\
\text { Objectivity,and } \\
\text { Intersubjectivity } \\
\text { UIN Sunan Kalijaga } \\
\text { Yogyakarta }\end{array}$ & M. Amin Abdullah \\
\hline
\end{tabular}

in the model of single entity or pure holy text without context, not in isolated entities or closed units as the normativity of the holy text itself, but rather in the model of interconnected entities between the three (Anshori \&Abidin, 2014).

The development of integrative Islamic science can be seen in the following table 1.

\section{Model of Science Integration with Islam}

The theory of Islamic integration with science primarily borrows the paradigm, epistemology and Ian G. Barbour's thought and Armahedi Mahzar dialogued with other Muslim intellectuals, such as Sayyid Hosein Nasr, Mehdi Gholshani, Murice Bucaille and Baiquni, some of whom have been discussed in the literature study segment. Paradigm theory and epistemology of Islamic science use the framework of Mahzar's Islamic integralism with guided Islamic scientific structure in general.

In Barbour-style mode of relationship between science and religion, the last two models meet philosophical standards and functional values - where dialogue is categorized as the initial stage of the integration model between science and religion while the pattern of integration relationships has its peak in unity and ingralism between science and religion. This paradigm became the ternd among contemporary theologians, including Islam. The choice of dialogue and integration are believed by theologians and scientists, including in the Muslim world, as the best way to build civilization based on science and religion.

In fact, the approach of science and religion emerged in the West starting from a conflict between the Bible and science where this is relatively not the case in the Islamic world except after the emergence of contradictions of some science domains such as the emergence of evolution theory and technological engineering with Islamic values. The approach of science and religion in the West assumes religion as a subjective knowledge and science as an objective knowledge. Consequently, religion as personal for each individual is distinguished from collective and social science. The spectrum of science-religious relations eventually strengthened and became the epistemological base of Western society. On the other hand, modern Muslim intellectuals are relatively do not mind about the relationship between religion and science which is seen as the perfecting of modern Western science.

Sayyed Husein Nasr reveals the existence of traditional Islamic science in the heyday of Islam using the same paradigm (because of the genealogy of science) with modern Western science. Therefore, the project of Islamization of knowledge as initiated by Sayyid Muhammad Naquib al-Attas at the First World Conference on Islamic Education in 1977 in Makkah is actually an attempt to de-westernization of science. Explicitly and unequivocally Ismail Raji al-Faruqi developed the term and project Islamization of Knowledge. This is the beginning 
of the integration of religion and science in the Islamic world (Mazhar, 2004). There is spectrum relationships between science and Islam with equally strong argument. One thing that can be taken as a conclusion is the agreement that the integration of religion and science is very possible and as an inability for Islam and Muslims to contribute to world civilization.

In an integral perspective, science is not only a set of knowledge but also the process of producing the dynamics development as well as its essential and functional roles. Science is not a static product that can be inserted with Islamic value directly, but needs to be balanced with the dynamics of science revolution (Mazhar, 2004). Therefore, Mahzar states the Islamization of science is a rational logical continuation of the ongoing paradigmatic reorientation of science with respect to external criticisms that associate the negative external impacts of science with the paradigm of modern science.

Mahzar offers a systematic process of building religious and scientific integration. The first stage is integration of the paradigm of atomism with the paradigm of cybernetic holism to create scientific objectivism view of theology. The second stage is to integrate the objective with the subjective view of religion and culture to create an integral and universal paradigm of science. In this new paradigm, religion, culture, science and technology become subjective, intersubjective, objective and inter-objectives aspects of the integral unity of human knowledge.

In integral unity, the hierarchical structure of traditional religious perennialism affects other dimensions to be appear as holarchy structure (Mazhar, 2004). The integralism is illustrated in this schematic table.

In Islam, the hierarchy structure is implied in tawhid, fiqh, Sufism and wisdom. Therefore, the islamization of the paradigm of universal integralism can naturally be directed towards Islamic integralism by replacing the holarchy of each quadrant with an implicit hierarchy in traditional Islamic thought.

The paradigm of Islamic integralism places religion not only in one quadrant, but on the basis of all quadrants. Objectivism ontology was replaced with Tauhidy theology and Hikmaty cosmology. The epistemology of religious subjectivism is replaced with sh叉f叉 epistemology while the actological intersubyektivism of culture is replaced by the axiology of the Fiqh. In such paradigm scheme, it is possible to unify the natural and social sciences paradigm with Islamic religious sciences paradigm. The paradigm of Islamic science is a combination of Tawhid that emphasizes the dimension of Ilahiyyah with the paradigm of wahdatiyyah that emphasizes the dimension of harmony.

\section{Paradigm of Integrative Islamic Science}

The term integrative Islamic science is basically an attempt at unifying science with Islam. Science in this case represents general science including natural sciences and social sciences is expected to be able to integrate with the Islamic sciences. Therefore, the term Islamic science is basically a new term that is now being developed to answer the challenges of an increasingly complex era.

Islamic science simply understood as a type of science in which knowledge of the physical world is embodied in Islamic views (Gulshanì et al., 2004). In other words, Islamic science can be understood as a science which contain Islamic scientific theories.

Among the scientists who popularized the term Islamic science was Armahedi Mahzar. Armahedi Mahzar's integrative Islamic science model has distinctive ontological, epistemological and axological configuration. He began by adopting and then systematically shifting the paradigm of modern science with Islamic paradigm (Qur'an, Hadith, and wisdom).

The construction of Islamic science is an integral epistemology-ontology-axiology of science that is identical to the integral unity of ulum al-din that is Sufism-fiqh-kalam. Ulûm al-dunya in Islamic perspective is closely intertwined with the ulûm al-din. The structure of philosophy or wisdom of ulum al-din can be an integrated paradigm for Islamic science. Thus, the paradigm of Islamic science can be referred to as the paradigm of tawhid because it emphasizes the dimensions of its ilahiyyah but can be referred to as the paradigm of wahdâtiyyah because it emphasizes cohesion.

This integration is the cohesion between all sciences including natural sciences, religious sciences, public sciences, and humanitarian sciences. The concrete and simple offer is that the sciences of society are Islamized with an integral

Table 2: Paradigm of Islamic Integralism

\begin{tabular}{lllll}
\hline Integral Categories & Epistemologi & Axology & Theology & Cosmology \\
\hline Source & Ruh & Qur'ani & Dzatullah & Tammah \\
Value & Qalb & Sunni & Shifatullah & Gha'iyyah \\
Information & 'Aql & Ijtihady & Amrullah & Shuriyyah \\
Energy & Nafs & Ijtima’y & Sunnatullah & Fa'iliyyah \\
Material & Jism & 'Urf & Khaqillah & Maddiyah \\
\hline
\end{tabular}


fiqhiyyah, the sciences of humanity are Islamized with shuffiyah, the natural sciences are islamized with tawhid. This means the cohesion between the ilm-hikmah-kitab (the alignment of science-philosophy-religion) (Mazhar, 2004).

The development of science has tremendously affecting human life. It was believed that science was originated from philosophy of mechanistic materialism which was full of greed. Therefore, the best solution to this problem is to change the spirit of science from materialistic to religious humanist. That means building a new science paradigm that is more integrative with religion (Islam) to create science with religious dimension.

In this contemporary era, there are many criticism toward modern science regarding the negative impact of science; (1) the destructive potential of mass destructive weapons by the military of great power, (2) pollution and destruction of the human environment by the massif industry, (3) social rifts, personal disfiance, and mental alienation brought about by urban lifestyles based on economic industrialization, and (4) misuse of drugs produced by the chemical industry. Therefore, some Muslim scientists began to endeavor to build the paradigm of Islamic science as an alternative to the new paradigm for post-modern science.

The purpose of modern science is to utilize nature for the improvement of human welfare but in the materialistisantroposentris paradigm which resulted in massive exploitation and destruction. Thus, a more holistic or integrative paradigm is needed- where Islam is one of the alternatives. In the Islamic science paradigm, science is positioned as part of humans transformative activities towards their environment in order to be grateful for the blessings of Allah. Islamic technology and science is a combination of technical and ethical values based on social values such as humanity, social culture, universal nature, and transcendental divinity.

Mahzar argues that Islamic science holds the epistemological, axological and ontological paradigms as an integral unit. The ontological paradigm of Islamic science is also integralistic. Islamic science sees the material structures as khalqillah or af'alullah or sunatul $\mathbb{\otimes} h$. Hence, the ontological paradigm is inseparable from Islamic theology. In the theological interpretation of the ontology of science, the evolutionary energetic process is the manifestation of natural laws that is His commandments (Amrullah), which are essentially manifestations of His attributes (Shifaullah) that manifest in the principles of holarchy values implicit in the natural laws and human culture. The many Shifatullah are the attributes of Dzatullh, the One Absolute substance as the creator of the universe.

Thus, it can be concluded that in Islamic science there is an ontological hierarchy identification of objects-phenomenonlaws-natural principles created by the Almighty, the theological hierarchy Khalq-Af'al-Amr-Shifat Allah. In addition, there is an identification of the epistemological hierarchy of objectsexperiments-principles-sources with the Shufiyyah psychology hierarchy jism-nafsi-'aqli-qalbi-ruhi. Similarly, there is a transcendental instrumental-socio-cultural-universal axiological heirarchy with a hierarchy of fiqhiyyah sources, namely 'urf-ijtima'-ijtihad Sunnah-Qur'an.

In the paradigm of integralism, integral unity of epistemology-ontology-actinology of science is identical to the integral unity of ulûm al-dîn, namely Sufism-fiqh-kalam. Therefore, ulûm al-dunya in islamic perspective is closely intertwined with the ulûm al-dinn. In fact, the philosophical structure or wisdom of ulum al-dîn can be an integrated paradigm for Islamic science. The paradigm of Islamic science can be referred to as tawhid paradigm because it emphasizes the ilahiyyah dimensions, as well as wahdâtiyyah paradigm because it emphasizes the dimension of cohesion. The construction of Islamic science illustrated in the following table 2.

The table illustrated the alignment between all sciences include security, religious sciences, public sciences, and humanitarian sciences. The concrete and simple offer is that the sciences of society are islamized with an integral fiqhiyyah, the sciences of humanity are islamized with sh凶fiyyah, the natural sciences are islamized with tawhid. This means the cohesion between the ilm-hikmah-kitab (the alignment of science-philosophy-religion) (Mazhar, 2004).

\section{Integrative Islamic Religious Education in Islamic Senior High School}

The development of teaching materials in islamic education subjects based on Integrative Islamic Science at SMA Al-Irsyad Al-Islamiyyah Purwokerto, SMA Andalusia Kebasen

Table 2: Integrative Islamic Science

\begin{tabular}{llll}
\hline Science base & Epistemeology & Axology & Ontology \\
\hline Source & Subject (Ruh) & Transcendental (Qur'an) & $\begin{array}{l}\text { Transcendence } \\
\text { (Dzatullah) }\end{array}$ \\
Value & Principle (Qalb) & Universal (Sunnah) & Holarki (Shifatullah) \\
Information & Theory \& facts ('Aql) & Cultural (Ijtihady) & Creativeness (Amrullah) \\
Energy & Experiment (Nafs) & Social (Ijtima'y) & Circulation (Sunatullah) \\
Material & Instruments/objects (Jism) & Instrumental ('Urf) & Systems (Khalqillah) \\
\hline
\end{tabular}


Banyumas, and SMA Ali Maksum, Krapyak, Yogyakarta uses development procedures in accordance with figure 2 adapted from the development research model from Sugiyono. The steps are: (1) Identifying the problems, (2) collecting the information, (3) designing interactive learning modules, (4) validating the design of interactive learning module, (5) revisioning the learning module design, (6) product creation, (7) limited trial, (8) product revision (9) readability trial, (10) product revision 2, and (11) product ready to use. The following is an explanation of the steps that have been taken (Sugiyono, 2010).

\section{Senior High School Andalusia Kebasen, Banyumas}

Senior High School Andalusia Kebasen, Banyumas is a public school based on pesantren (Islamic boarding school). As a relatively new school, this school able to compete with more "senior" schools in Banyumas and surrounding areas. Among the characteristics of religious integrate models and design at this school are:

- School as a formal educational institution positioned under the boarding school. This is because boarding schools are established much earlier than the school;

- Senior High School Andalusia, Kebasen, Banyumas obligate all students to live in the boarding school (pesantren) even though their house may or may not close to the school;

- In the learning process, Islamic Religious Education teachers always use references to Salaf books (read: yellow book) to extend the material delivered to the students;

- In the process of integrating between religion and science, Islamic Religious Education (PAI) teachers always coordinate with science teachers to associate both materials (Islam-science) to establish the correlation between the two.

\section{Senior High School Al Irsyad Al Islamiyyah, Purwokerto}

- As one of the leading private schools in Purwokerto, SHS Al Irsyad Al Islamiyyah Purwokerto is committed to integrate Islamic science.

- The efforts to integrate religion and science are carried out by connecting Islamic Religious Education (PAI) subjects with natural and social sciences subjects such as biology, physics, chemistry or geography, economics, geography

- In the learning process, if the students asks the teacher related to other subjects, the teacher will explain in accordance with the teacher's capacity.

- The teachers board of science subjects always emphasizes to students that the science material they learn is essentially the science of Allah SWT (religious science) which ultimately must be the character of the learner.

\section{Senior High School Ali Maksum, Krapyak, Yogyakarta}

- Schools as formal educational institutions have position under boarding schools. This is because boarding schools are established much earlier than the school;

- Students are obligate to live in the Islamic boarding school (pondok pesantren) even though they may live near the school;

- In the learning process, Islamic Religious Education (PAI) teachers always use references to salaf books (read: yellow book) to extend the material delivered to students;

- In the process of integrating between religion and science, Islamic Religious Education (PAI) teachers always coordinate with science teachers to associate both materials (Islam-science) to establish the correlation between the two.

\section{Conclusion}

Teaching Materials for Islamic Religious Education which integrate Islamic Science for Class X Islamic Senior High School has been produced for SMA Al-Irsyad Al Islamiyyah Purwokerto, SMA Andalusia Kebasen Banyumas and SMA Ali Maksum, Krapyak, Yogyakarta. The textbook produced through 11 development steps; (1) Identifying problems, (2) collecting the information, (2) designing the learning modules, (4) validating the learning modules, (5) revisioning the learning module design, (6) product creation, (7) limited trials, (8) product revisions (9) readability trials, (10) product revisions 2, and (11) ready-to-use products. After going through all the development steps, the Islamic Religious Education Material Integrative Islamic Science for Class X in Islamic Senior High School deserves to be used as a means of self-learning students and learning media in the classroom.

The feasibility level of Islamic Religious Education Integrative Islamic Science Class X of Islamic Senior High School is determined by four product assessment activities; material expert validation, media expert validation, limited trials, and readability trials. The results of the validation of material experts from 8 aspects of the assessment obtained on average 3.33 and classified as "Excellent", the validation results of media experts from 7 aspects of the assessment obtained on average 3.23 with "Good" classification, limited trials of 2 aspects of the assessment obtained an average of 3.54 classified as "Excellent" and the legibility trials of the 2 aspects of the assessment obtained an average of 3.60 with "Excellent" classification. The total average is 3.43 in the "Excellent" classification.

\section{References}

Abdullah, A. (2003). New horizon of islamic studies throught sociocultural hermeneutics. Al-Jami'ah: Journal of Islamic Studies, 41(1). https://doi.org/10.14421/ajis.2003.411.1-24

Abdullah, M. M. (2019). Practice of use of materials to teach islamic education teachers of religious high school. International Journal of Academic Research in Progressive Education and 
Development, 8(4), 1088-1093. https://doi.org/10.6007/ IJARPED/v8-i4/6908

Aminuddin, L. H. (2010). Integrasi ilmu dan agama: studi atas paradigma integratif interkonektif UIN Sunan Kalijaga Yogjakarta. Kodifikasia: Jurnal Penelitian Islam, 4(1), 1-34. https://doi.org/10.21154/kodifikasia.v4i1.746.

Andi, P. (2012). Panduan kreatif membuat bahan ajar inovatif. Diva Press.

Anshori, A., \& Abidin, Z. (2014). Format baru hubungan sains modern dan islam (studi integrasi keilmuan atas UIN Yogyakarta dan tiga uinversitas islam swasta sebagai upaya membangun sains islam seutuhnya tahun 2007-2013).

Bhat, A. M. (2016). Human psychology (fitrah) from islamic perspective. International Journal of Nusantara Islam, 4(2), 61-74. https://doi.org/10.15575/ijni.v4i2.1187

Efrinaldi, E., Andiko, T., \& Taufiqurrahman, T. (2020). The paradigm of science integration in islamic university: the historicity and development pattern of islamic studies in Indonesia. Madania: Jurnal Kajian Keislaman, 24(1), 97. https:/doi.org/10.29300/ madania.v24i1.3326

Gulshanī, M., Muhammad, A., \& Baiquni, A. (2004). Melacak jejak tuhan dalam sains: tafsir islami atas sains. Mizan. https:// books.google.co.id/books?id=OeH2nQAACAAJ

Hossain, M. I. (2015). Teaching productive skills to the students: a secondary level scenario. BRAC University.

Johar, R., \& Hanum, L. (2016). Strategi belajar mengajar. Deepublish.

Lickona, T. (2009). Educating for character: how our schools can teach respect and responsibility. Bantam.

Lickona, T. (2012). Character matters (persoalan karakter): bagaimana membantu anak mengembangkan penilaian yang baik, integritas, dan kebajikan penting lainnya. Bumi Aksara.
Makbuloh, D., \& Ruswanto. (2020). A model of the integration of science in state islamic universities in indonesia. advances in social science, education and humanities research, 492(RIICMuSSS 2019), 154-157. https://doi.org/10.2991/ assehr.k.201113.029

Mazhar, A. (2004). Revolusi integralisme islam, merumuskan paradigma sains islami. Mizan.

Mudlofir, A. (2011). Aplikasi Pengembangan kurikulum tingkat satuan pendidikan dan bahan ajar dalam pendidikan agama islam. Raja Grafindo Persada.

Mustahdi \& Mustakim. (2014). Pendidikan agama islam dan budi pekerti untuk SMA/MA/SMK/MAK Kelas XI. Balitbang Kemendikbud.

Nasrullah, N. (2016). Rekonstruksi objektif dan subjektif dalam pemikiran islam (studi penafsiran Abdul Hamid Hakim tentang ahli kitab). SYAHADAH: Jurnal Ilmu Al-Qur'an Dan Keislaman, 5(1).

Nugroho, B. T. A. (2017). Integration of islamic education with science and technology in islamic junior high school. MUDARRISA: Jurnal Kajian Pendidikan Islam, 9(1), 1-27. https://doi. org/10.18326/mdr.v9i1.1-27

Riyanto, W. F. (2013). Integrasi-Interkoneksi keilmuan: biografi intelektual M. Amin Abdullah (1953-...), person, knowledge, and institution. Yogyakarta: Suka Press.

Sugiyono, S. (2010). Metode penelitian kuantitatif dan kualitatif dan $R \& D$. Alfabeta.

Sunhaji, S. (2013). Pembelajaran tematik-Integratif: pendidikan agama Islam dengan science. STAIN Press.

Trianto. (2012). Model pembelajaran terpadu: konsep, strategi dan implementasinya dalam kurikulum tingkat satuan pendidikan (KTSP). Bumi Aksara. 